\title{
Flood risk, climate change and settlement development: a micro-scale assessment of Austrian municipalities
}

\author{
Lukas Löschner ${ }^{1} \cdot$ Mathew Herrnegger $^{2} \cdot$ Benjamin Apperl $^{2} \cdot$ Tobias Senoner $^{2}$ \\ Walter Seher ${ }^{1} \cdot$ Hans Peter Nachtnebel ${ }^{2}$
}

Received: 11 November 2015 / Accepted: 12 June 2016/Published online: 2 July 2016

(C) The Author(s) 2016. This article is published with open access at Springerlink.com

\begin{abstract}
This paper analyses the influence of climate change and land development on future flood risk for selected Austrian flood-prone municipalities. As part of an anticipatory micro-scale risk assessment we simulated four different inundation scenarios for current and future 100and 300-year floods (which included a climate change allowance), developed scenarios of future settlement growth in floodplains and evaluated changes in flood damage potentials and flood risk until the year 2030. Findings show that both climate change and settlement development significantly increase future levels of flood risk. However, the respective impacts vary strongly across the different cases. The analysis indicates that local conditions, such as the topography of the floodplain, the spatial allocation of vulnerable land uses or the type of land development (e.g. residential, commercial or industrial) in the floodplain are the key determinants of the respective
\end{abstract}

Editor: Juan Ignacio Lopez Moreno.

Electronic supplementary material The online version of this article (doi:10.1007/s10113-016-1009-0) contains supplementary material, which is available to authorized users.

Lukas Löschner

lukas.loeschner@boku.ac.at

Mathew Herrnegger

mathew.herrnegger@boku.ac.at

Benjamin Apperl

benjamin.apperl@boku.ac.at

Tobias Senoner

tobias.senoner@boku.ac.at

Walter Seher

walter.seher@boku.ac.at

Hans Peter Nachtnebel

hans_peter.nachtnebel@boku.ac.at effects of climate change and land development on future levels of flood risk. The case study analysis highlights the general need for a more comprehensive consideration of the local determinants of flood risk in order to increase the effectiveness of an adaptive management of flood risk dynamics.

Keywords Flood risk assessment $\cdot$ Flood damage $\cdot$ Hazard exposure $\cdot$ Climate change $\cdot$ Settlement development

\section{Introduction}

Flood risk can be defined as the combination of the probability of a flood event and its potential adverse consequences (Smith 1996; Sayers et al. 2002; UNISDR 2009). As both aspects of risk—hazard and vulnerability—are nonstationary, flood risk is a "dynamic entity" (Merz et al. 2010). This changeable characteristic of flood risk is emphasized in the EU Floods Directive (2007/60/EC), which specifies that "...human activities (such as increasing human settlements and economic assets in floodplains...)

1 Department of Landscape, Spatial and Infrastructure Sciences (RALI), Institute of Spatial Planning and Rural Development (IRUB), University of Natural Resources and Life Sciences, Vienna (BOKU), Peter-Jordan-Straße 82, 1190 Vienna, Austria

2 Department of Water - Atmosphere - Environment (WAU), Institute of Water Management, Hydrology and Hydraulic Engineering (IWHW), University of Natural Resources and Life Sciences, Vienna (BOKU), Muthgasse 18, 1190 Vienna, Austria 
and climate change contribute to an increase in the likelihood and adverse impacts of flood events" (EU 2007).

A key indicator for the spatiotemporal dynamics of flood risk is the observed increase in flood damages over the last decades (Barredo 2009; Kreft 2011; UNISDR 2011). This increase can be attributed to socio-economic factors, including settlement growth near rivers and the rise in the concentration of values in these areas (Evans et al. 2004; Barredo 2009; Munich Re 2013), which has been confirmed in numerous empirical analyses. A German study of a Mulde sub-catchment, for instance, showed that land-use change in the form of urban sprawl is a key driver of flood risk (Elmer et al. 2012). Similarly, a study on the development of flood exposure in the Netherlands found that socio-economic change and the increase in urban area in flood-prone zones have led to an exponential increase in potential flood damage during the twentieth century (de Moel et al. 2011). More specifically, in a prospective analysis of future socio-economic change in a Dutch dike ring Bouwer et al. (2010) calculated a 35-172\% increase in expected damage by 2040 compared to the year 2000 .

While there is a general consensus that land development in floodplains has and will continue to have an immediate effect on flood risk, empirical findings concerning the climate change-related influences are less clear. According to the fifth IPCC assessment report (Hartmann et al. 2013), there is a low confidence regarding the sign of a trend in the magnitude and/or frequency of floods on a global scale over the instrumental period. It is also stated that "with high confidence, floods larger than recorded since the twentieth century occurred during the past five centuries in northern and central Europe, the western Mediterranean region and eastern Africa". For Europe, although there is some evidence of a general increase in extreme precipitation, no conclusive evidence is available for climate-related trends of extreme flow for the future (Barredo 2007, 2009; Kundzewicz 2012; Madsen et al. 2014).

In Austria, due to the complexity and the topographically induced variability of the Alpine climate, regional climate models are especially uncertain regarding the prediction of future changes in frequency and magnitude of floods (APCC 2014; BMLFUW 2011a; OeWAV 2010). A comprehensive study of climate change impacts on flood frequency shows no clear climate signal for Austria (Nachtnebel et al. 2014). Blöschl et al. (2011), on the other hand, report on the basis of several if-then scenario simulations that future changes for flood peaks with a return period of 100 years are in the range of -4 to $+10 \%$.

Although no conclusive evidence and projections exist concerning changes in flood frequency and magnitude, it is clear that climate change is influencing and will further influence components of the Alpine hydrological cycle, e.g. due to higher temperatures or rising snowlines (APCC 2014; HISTALP 2013). Daily precipitation amounts and annual maximum daily precipitation are anticipated to increase over many areas (Christensen and Christensen 2002; Kundzewicz et al. 2010), increasing the probability that climate change will lead to more severe floods in the Alps (Formayer and Kromp-Kolb 2009; Gobiet et al. 2014).

Since future changes in flood risk may be affected by both climate change and settlement development in floodplains, this contribution analyses the driving mechanisms of future flood risk dynamics by the example of three Austrian flood-prone municipalities. As part of an anticipatory flood risk assessment, a climate change allowance for 100- and 300-year floods was implemented, scenarios of future settlement growth in floodplains were developed, and expected changes in flood damage potentials and flood risk until the year 2030 were evaluated. The aim of this anticipatory assessment was to identify (1) the (individual and combined) effects of climate change and settlement development on future levels of flood risk and (2) the local context conditions which determine whether climate change or land development is the driving factor of future flood risk. As flood risk assessments are always a means to an end-their aim is not just to improve the quality of the risk assessments per se but to ensure that these assessments provide an evidence base for flood management measures (OeWAV 2014) - this contribution identifies emerging flood risks in order to assist local and regional decision makers in adapting to changing levels of flood risk.

\section{Materials and methods}

This section describes the methodological approach of the micro-scale risk assessment. In order to better understand the individual components of the risk assessment, some key terms shall be defined based on the "Language of Risk" published by the consortium of the FLOODsite FP6 project (Gouldby and Samuels 2005). As this study focuses on inland river floods, the term flood refers to the temporary covering of land by water outside its normal confines. Flood events present a hazard to the environment and can be described through their intensity and consequences. The intensity can be defined via physical parameters, e.g. spatial extent of the inundated area, water depth, flow velocity or flood duration. The intensity is usually related to a defined discharge value with an associated return period (e.g. $\mathrm{HQ}_{100}$ or $\mathrm{HQ}_{300}$ ). Flood hazard is defined as a process, which may lead to adverse consequences in the form of damage or loss if material goods and/or living beings are affected. The effects of a hazard are determined based on the exposure and vulnerability of these elements. Flood 
exposure indicates which receptors may be influenced by a flood hazard, i.e. which elements are located in a defined inundation area. Vulnerability defines how susceptible an object is to damage, i.e. its potential to be harmed. Susceptibility describes the propensity of a particular receptor to experience harm, which can be expressed in terms of an actual loss. The upper limit of the loss or damage is defined by the damage potential. It constitutes the value of social, economic and ecological impacts (harm) that would be caused in the event of a flood. Flood risk is the combination of the probability of a flood event and of the potential adverse consequences for human health, the environment, cultural heritage and economic activity associated with a flood event (EU 2007). The measure of risk can be defined as a mathematical function of the probability of occurrence of a specific flood event (hazard) and the adverse consequences (vulnerability, including exposure). In this study, flood risk is thus expressed in form of the expected value of economic losses, defined as the mean annual loss (Nachtnebel et al. 2013). The mean annual loss is calculated by a numeric approximation via known damage potentials of $\mathrm{HQ}_{100}$ and $\mathrm{HQ}_{300}$. Normally a much larger number of events should be considered for the calculation of the mean annual loss. These events are, however, not available for the study, and the information is limited for the two return periods. The absolute values of annual expected damages are therefore afflicted with noteworthy uncertainties. It can, however, be expected that the relative changes in the mean annual losses are nevertheless more trustworthy.

\section{Description of study areas}

In this study, a micro-scale assessment of future flood risk (for the year 2030) was conducted for three Austrian municipalities. The cases were selected based on a macroscale risk assessment for Austria (Nachtnebel and Apperl 2015; Nordbeck et al. 2015). Although the availability of hydrodynamic models and digital municipal zoning plans was a limiting factor for case selection, the following three flood-prone municipalities were chosen in consideration of the spatial variability (type of land uses, geographic/topographic conditions) of Austrian municipalities (see Fig. 1):

- Gleisdorf is a small peri-urban municipality $\left(4.8 \mathrm{~km}^{2}\right.$; 6.150 inhabitants; $360 \mathrm{~m}$ above sea level) located along the River Raab in the Austrian Federal State Styria. The municipality is an important regional commercial centre with high population growth $(+11 \%, 2001-2013)$. A flood retention reservoir protects the current settlement areas against floods with a return period of 100 years. Future land-use options are generally constrained by a lack of available land for housing development, and large areas of open land for industrial and commercial developments are located near the River Raab, just outside the 100-year flooding zones.

- Altenmarkt im Pongau is a large alpine municipality (48.6 $\mathrm{km}^{2} ; 4.560$ inhabitants; $840-1.350 \mathrm{~m}$ above sea level) located along the upper stretch of the River Enns in the Austrian Federal State Salzburg. With only around $18 \%$ of its total area suitable for permanent

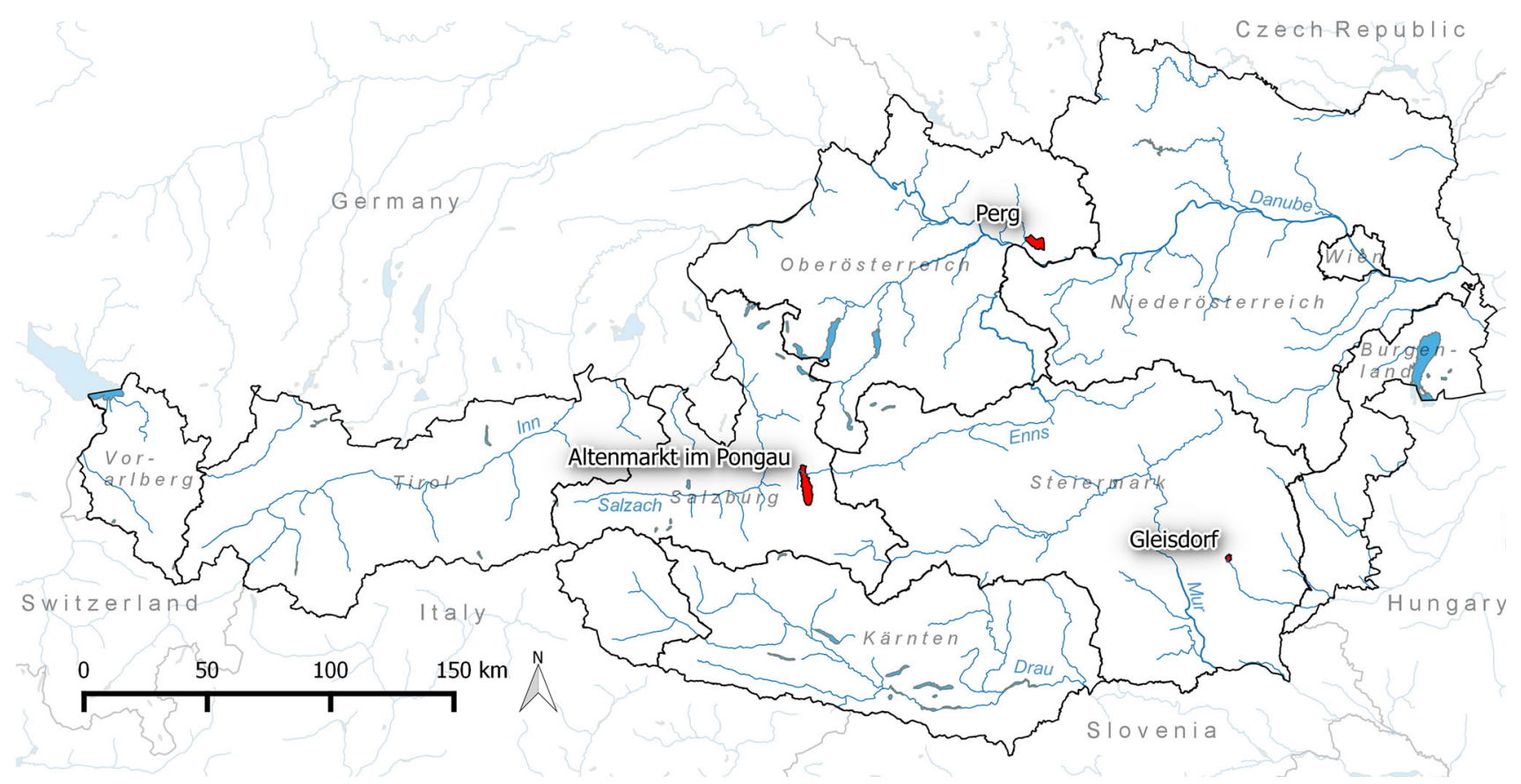

Fig. 1 Location of the three case study municipalities in Austria 
settlement due to the alpine topography, vulnerable land uses as well as future areas of land development are concentrated in the lower areas of the valley. A popular (winter) tourism destination and an important regional economic centre, Altenmarkt is characterized by dynamic population growth $(+8.7 \%, 2001-2013)$. A recently imposed flood protection scheme (incl. a flood retention reservoir) protects settlement areas against floods with a return period of 100 years.

- Perg is a small Upper Austrian city $\left(26.5 \mathrm{~km}^{2} ; 8.580\right.$ inhabitants; $250 \mathrm{~m}$ above sea level) located at the lower reach of the River Naarn. The city provides important socio-economic functions as the region's commercial, residential, administrative and educational centre. With around $86 \%$ of its area suitable for permanent settlement and a large share of agricultural land, the municipality has sufficient vacant land to accommodate a growing residential population $(+12.5 \%, 2001-2013)$ and a dynamic commercial sector. The city has some flood protection infrastructure; however, it is not protected against floods with a 100-year return period.

\section{Assessing current and future flood hazards}

The flood hazard assessment is based on simulations with hydrodynamic models, which were provided for the selected municipalities by the provincial governments. Initially, the models had been established for the generation of flood hazard and flood risk maps, as demanded by the European flood directive for areas with potentially significant flood risk (BMLFUW 2011b). The simulations had been performed with the $2 \mathrm{D}$ hydrodynamic model Hydro_AS-2D (Hydrotec 2014) and include inundation areas and inundation depths for current design floods with return periods of 100 and 300 years. The hydrodynamic models of the case study areas were used as a basis for the analysis of current and future flood hazard.

For the analysis of the sensitivity of potential climate effects on the flood hazard, it was necessary to adapt the current models, particularly the input design flood values. Kundzewicz et al. (2010) recommend the adjustment of design floods using a "climate change factor" approach. They state that "due to the large uncertainty of climate projections" (which is especially true for Alpine areas), "it is currently not possible to devise a scientifically sound procedure for redefining design floods". In Europe, several guidelines defining climate change factors on design floods exist. The adjustment factors, however, vary considerably, ranging from an increase of 0-75\%, depending on catchment size, location and return period (Madsen et al. 2014).

For this study, a climate change allowance of $10 \%$ was introduced to the current peak discharges of 100-year flood events $\left(\mathrm{HQ}_{100}\right)$ and 300-year flood events $\left(\mathrm{HQ}_{300}\right)$. The design flood of $\mathrm{HQ}_{100}$ reflects floods of a medium probability as stated in the EU Floods Directive and generally corresponds to the subsidized level of protection for settlements in Austria, while the design flood of $\mathrm{HQ}_{300}$ represents an extreme event scenario with a low probability. The $10 \%$ allowance was chosen based on a comprehensive study of climate change adaptation in Austrian water policy (BMLFUW 2011a; Blöschl et al. 2011). In the study, future changes were assessed for the period 2021-2050 (in reference to current climate conditions for the period 1976-2007) based on the IPCC Multimodel Ensemble (CMIP3). For the down-scaling to the regional scale in Austria the study used findings of the model COSMOCLM (powered by the global model ECHAM5 for the scenario A1B) and compared them with the REMO model. To account for the large uncertainties related to future changes in flooding the study calculated several if-then scenarios, in which different mechanisms leading to floods were varied. These included changes in winter and summer precipitation, rising snow lines, increase in convective precipitation, earlier snowmelt and higher evapotranspiration. The scenario analysis showed that in Austrian regions future changes for flood peaks with a return period of 100 years are in the range of -4 to $+10 \%$. In this study, the applied climate factor corresponds to the upper end of the possible range of changes in extreme flows and thus presents a worst-case assumption of possible climate change-based impacts on future flood hazard in Austria. The introduction of the climate change allowance to the current peak discharge values can also be interpreted as a sensitivity analysis, since the uncertainties of changes in design flood values for the future based on climate models are still very large. The $10 \%$ climate change factor applied in this study is comparable to the approach used in the German state of Bavaria, which augments the 100-years flood by $15 \%$ and the 300-years flood by $7.5 \%$ to account for future uncertainties due to climate change (Hennegriff et al. 2006; LfU 2005).

Accordingly, in this study the inundation areas and depths were simulated for the following four scenarios:

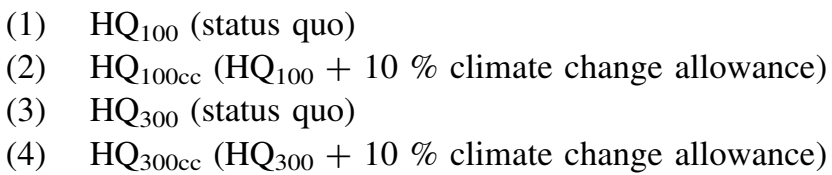

The results of the hydrodynamic simulations were exported and processed with ArcGIS and QGIS. For each scenario, shapefiles defining the extent of the inundation area, including two classes of inundation depths $(\leq 0.5$ and $>0.5 \mathrm{~m}$ ), were generated. 


\section{Assessing current and future flood hazard exposure}

The assessment of future flood hazard exposure is based on an assessment of the current exposure of risk elements and includes scenarios of settlement development until the year 2030. Although decisions in flood risk management often have long-term consequences of fifty years and more (Evans et al. 2004; Hallegate 2009), this study uses a comparatively short-term time frame of fifteen years, which corresponds with that of municipal zoning and land use plans in Austria. This allows for a detailed assessment of future settlement trajectories based on existing planning documents.

For the assessment of current flood hazard exposure, the calculated inundation areas and inundation depths of all hazard scenarios $\left(\mathrm{HQ}_{100}, \mathrm{HQ}_{100 \mathrm{cc}}, \mathrm{HQ}_{300}\right.$ and $\left.\mathrm{HQ}_{300 \mathrm{cc}}\right)$ were intersected in ArcGIS with the (geo-referenced) Austrian federal building and housing register to determine which types of buildings (e.g. residential, commercial, industrial or public buildings) are flooded to which extent, i.e. affected building area (see Online Resources 1-3).

For the assessment of future changes in flood hazard exposure, a scenario of settlement development until the year 2030 was generated for each case study. On the basis of census and economic data for the years 1991, 2001 and 2011 and based on the analysis of current spatial planning documents (i.e. municipal zoning plans, regional development plans), the expected changes in population and household size, the expected availability of building land reserves and the expected demand for housing and commercial/industrial land uses were evaluated. The scenarios of settlement development were complemented by in situ knowledge of local authorities (mayors, chief officers and heads of the municipal building department) and the municipalities' spatial planning consultants. In the course of in-depth interviews they were asked (1) to comment on expected trajectories of land development in their municipality, (2) to identify priority areas of settlement development and (3) to specify the type of expected development on vacant plots or the predictable demolition of buildings until the year 2030. The local authorities' input was used to validate assumptions and to check the plausibility of the exposure scenarios.

The expected settlement development in the calculated flooding areas was mapped in ArcGIS (see Fig. 2). For the assessment of future hazard exposure, the projected development of new buildings was merged with the building and housing register and intersected with the respective flooding scenarios.

\section{Evaluating damage potentials and flood risk}

Generally, the estimation of flood damages distinguishes between direct and indirect as well as tangible and intangible damages (Messner and Meyer 2006; Schanze et al. 2008;
Smith and Ward 1998) and considers the susceptibility of each object, such as the long-term impacts of a hazardous event. Due to the uncertainties related to the quantification of indirect damages (Barredo 2009), this study only analyses the direct monetary damages. The estimation of the damage potential is based on the total value of objects at risk (Merz et al. 2004). The damage potential may change due to an enlarged inundation area as well as due to land development, e.g. the transformation of an agricultural area into a residential area (Nachtnebel and Apperl 2015).

In this study, objects at risk were classified and assigned specific damage or loss functions, whereas the potential damage was differentiated according to the following flooding intensities (see Table 1): (1) not affected, (2) low intensity (water depth $\leq 0.5 \mathrm{~m}$ ) and (3) high intensity (water depth $>0.5 \mathrm{~m}$ ). The specific damage functions have the dimension $€ / \mathrm{m}^{2}$ for buildings. The damage potential calculation, therefore, takes the area of objects at risk into account. The monetary values are based on data from BUWAL (1999a, b) in Switzerland, adapted for Austria and discounted to price levels of 2014 by Nachtnebel et al. (2013) and Nachtnebel and Apperl (2014).

As damage functions are subject to considerable uncertainty (e.g. Merz et al. 2004), the indicated values are approximations of damage potentials. For the purpose of this study, the values, however, enable a consistent comparison across the analysed cases and scenarios. Flood risk is quantified for all cases in form of the total damage potential and the mean annual expected damage. The current and potential future flood damages in the municipalities were calculated for the different flood events $\left(\mathrm{HQ}_{100}, \mathrm{HQ}_{100 \mathrm{cc}}, \mathrm{HQ}_{300}\right.$ and $\mathrm{HQ}_{300 \mathrm{cc}}$ ). The damage assessment does not consider possible structural failures of flood defence infrastructure. It is assumed that the flood defence infrastructure (i.e. flood retention reservoirs) loses their function, if the flood is larger than the design flood it was constructed for. This is the case for Gleisdorf and Altenmarkt for $\mathrm{HQ}_{100 \mathrm{cc}}$, since the flood retention reservoirs were designed for a $\mathrm{HQ}_{100}$. For the events larger and equal to $\mathrm{HQ}_{100 \mathrm{cc}}$, we assumed in the calculations that no flood retention reservoirs are available.

\section{Results}

This section presents findings from the assessment of future changes in flood hazard and exposure and illustrates expected changes in flood damage potentials and flood risk for the three Austrian cases.

\section{Climate change impacts on future flood hazard}

The potential impact of climate change on the inundation areas is different for the three case studies, as shown in 


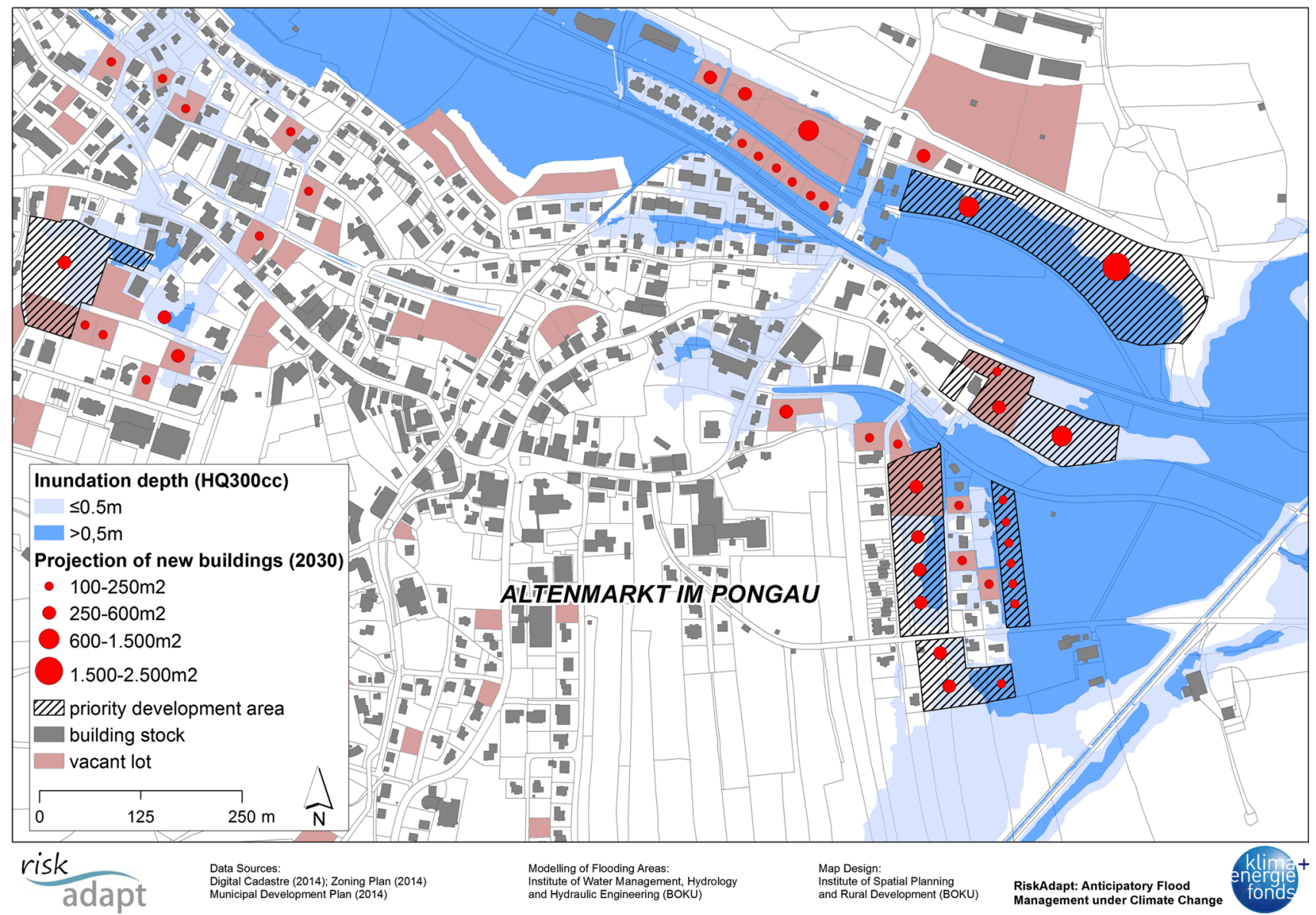

Fig. 2 GIS-based mapping of future settlement trajectories in flooding areas with the maximum calculated design flood $\mathrm{HQ}_{300 \mathrm{cc}}(\mathrm{detail}$ from the Altenmarkt case study)

Table 1 Specific damage functions in $€ / \mathrm{m}^{2}$ for different building types and water depths for all case studies and return periods

\begin{tabular}{llll}
\hline Building category & Building type & $\begin{array}{l}\text { Water depth } \leq 0.5 \mathrm{~m} \\
\text { Specific damage in } € / \mathrm{m}^{2}\end{array}$ & Water depth $>0.5 \mathrm{~m}$ \\
\hline Residential buildings & Single-family houses & 125 & 750 \\
& Apartment buildings & 150 & 830 \\
Commercial and public buildings & Offices and other commercial buildings & 435 & 1.975 \\
& Schools and other public buildings, Hotels & 150 & 830 \\
Industrial complexes & Industrial buildings & 530 & 2.765 \\
& Storehouses & 16 & 160 \\
\hline
\end{tabular}

Fig. 3 and in the additional maps in Online Resources 1-3. In Perg, the climate change allowance increases the extent of the flooded area by $15 \%$ for a 100-year flood event (see $\mathrm{HQ}_{100}$ vs. $\mathrm{HQ}_{100 \mathrm{cc}}$ ) and by $13 \%$ for a 300 -year flood event (see $\mathrm{HQ}_{300}$ vs. $\mathrm{HQ}_{300 \mathrm{cc}}$ ). In Gleisdorf, the respective climate change effects are $+83 /+40 \%$, in Altenmarkt $+11 /$ $+10 \%$.

The different impacts of climate change on the inundation area reflect the level of flood protection in the case studies as well the topographic conditions in the respective floodplains. In Perg, the relatively high share of building land affected by the 100-year flood event (4.5\%) and the linear increase in flooding area illustrate the lack of flood protection in the municipality. Due to the flat topography of the floodplain, the climate change allowance leads to a large absolute increase in the inundation area (albeit with low inundation depths). In Gleisdorf, the sharp increase in the share of affected building land (of the total flooded 


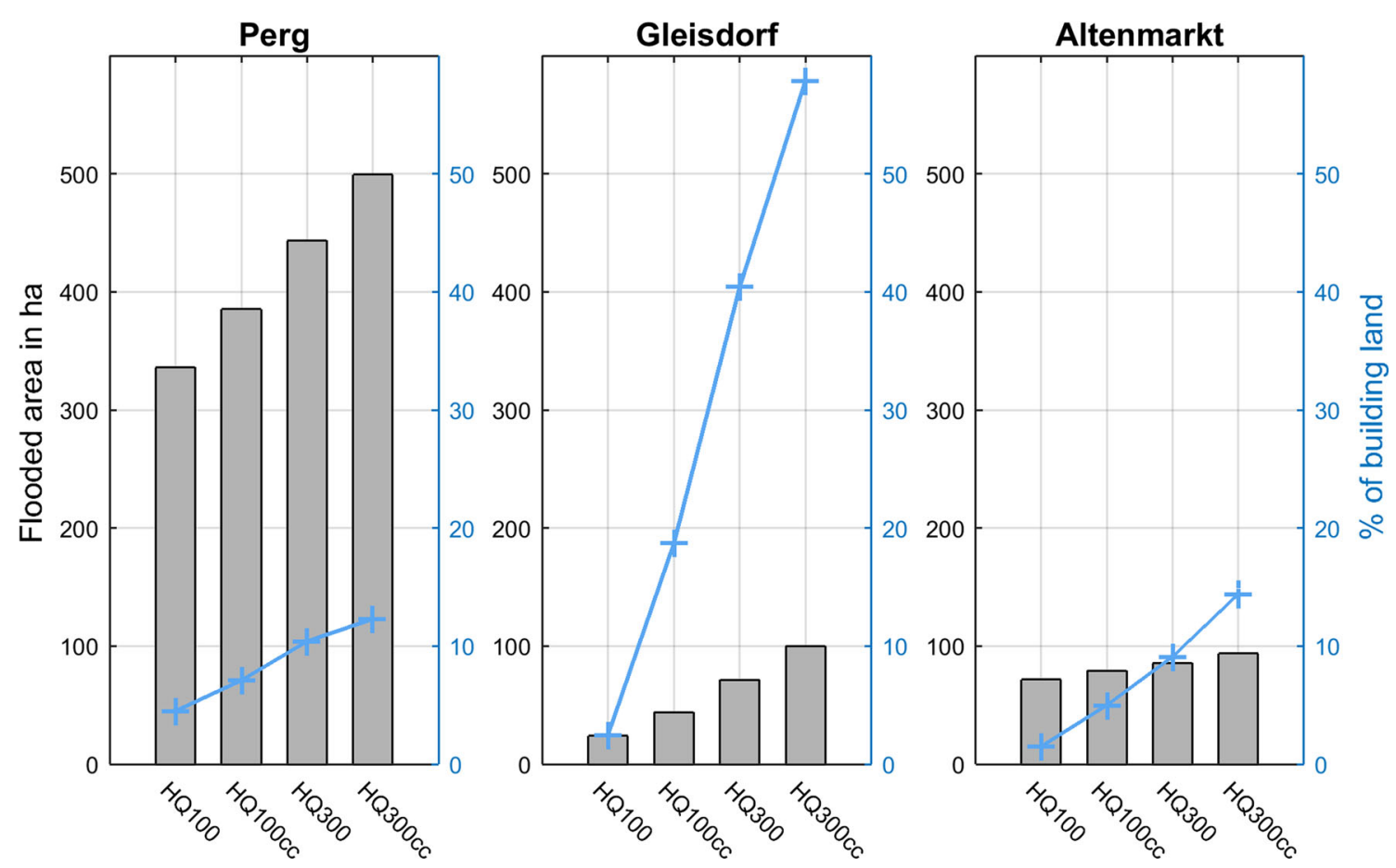

Fig. 3 Inundated area for current and future design floods for the three case studies

area) from $2.5 \%\left(\mathrm{HQ}_{100}\right)$ to $18.7 \%\left(\mathrm{HQ}_{100 \mathrm{cc}}\right)$ shows that the flood protection infrastructure (in particular the flood retention reservoir) would lose its function in the case of a climate change-based increase in the flood peak. The large share of affected building land in flood events $>\mathrm{HQ}_{100}$, moreover, reflects the high building density in the floodplain. Finally, the floodplain in the alpine case study Altenmarkt is characterized by steeper gradients, as becomes evident in the relatively small increase in the flooding areas. Especially in extreme events $\left(>\mathrm{HQ}_{100}\right)$, significant parts of the flooding would occur on building land, again indicating that floodplains are highly attractive areas for settlement development.

\section{Land development impacts on future flood hazard exposure}

In addition to the strong variation in the amount of building land affected, the analysis of flood hazard exposure also shows significant differences among the case studies regarding the types of buildings exposed to flooding as well as regarding the influence of land development on future exposure (Fig. 4).

Concerning the type of flood hazard exposure, the findings indicate that in Perg and Altenmarkt predominately residential buildings (i.e. single-family houses and apartment buildings) are exposed to flooding. In Gleisdorf, on the other hand, commercial buildings as well as industrial complexes (i.e. industrial buildings and warehouses) make up the majority of potentially affected building area.

With regard to future changes in flood hazard exposure, Fig. 4 illustrates that the projected land development in floodplains (until the year 2030) is expected to lead to an increase in flood hazard exposure in all three cases, although the intensity and the type of land development vary considerably. In Perg, the currently affected building area is expected to just slightly increase in the future. Aside from the realization of small residential housing units, the scenario of land development depicted in the figure comprises the construction of a residential housing project in an area currently used by a transport and logistic company (whose building complex will be relocated to a flood-safe business park). In Altenmarkt, on the other hand, largescale land development is to be expected in the floodplain. The municipality thus faces the sharpest increase in future flood hazard exposure of the observed cases. In addition to more than forty residential buildings (single-family as well as apartment houses), commercial buildings and industrial complexes are to be developed in the floodplain. About one-third of these new buildings shall be constructed within the 100-year flooding zone, leading to a particularly strong increase in flood hazard exposure in this flooding scenario. Finally, in Gleisdorf flood hazard exposure is expected to only moderately increase in the next years. Based on the land development scenario, no residential buildings shall be developed in the floodplain; however, additional commercial and industrial buildings (e.g. 


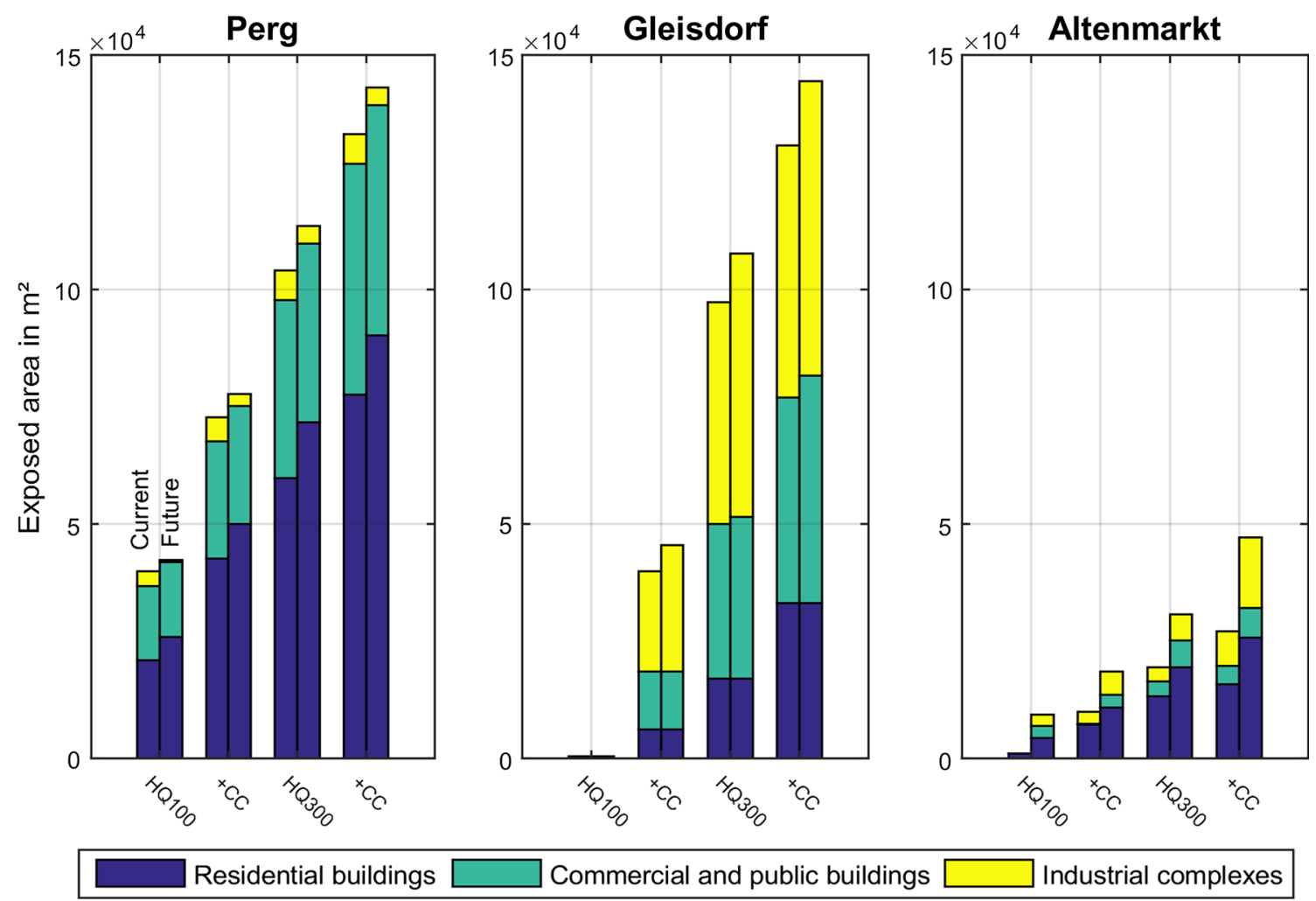

Fig. 4 Case study comparison of current and future building categories affected in the flooding scenarios. The first and second columns for every flooding scenario refer to the current and future land use

manufacturing and warehouses) are likely to be constructed in the flood-prone area, albeit outside the 100-year flooding zone.

\section{Expected change in flood damage potentials and flood risk}

Based on the specific damage functions (see Table 1), the damage potential was calculated for floods with 100- and 300 -year return periods for (1) the status quo, (2) the climate change scenario under the assumption of current land use, (3) the land development scenario with current flood return periods and (4) the combined scenario of climate change and land development (see Fig. 5).

Findings show that the impact of the different scenarios on future flood damage potential varies considerably. In Perg, the current damage potential of approx. $€ 16$ million for $\mathrm{HQ}_{100}$ is expected to increase to about $€ 23.2$ million or by $46 \%$ under the calculated climate change scenario. Land development, on the other hand, would not significantly influence the total flood damage, although the composition of flood damages is likely to change due to the development of residential buildings on the current site of an industrial complex. For floods with a 300-year return period, climate change would increase flood damages from approx. $€ 32.7$ million to $€ 43.2$ million or by approx. $32 \%$. Land development with a current 300-year flood would only lead to a change in damage potential of about $+5 \%$. Consequently, in the worst-case scenario (climate change and land development) flood damages are only slightly higher $(+36 \%)$ compared to the climate change scenario (under the assumption of current land use). The driving factor of the damage potential in Perg can therefore be mainly attributed to the climate change signal.

In Gleisdorf climate change is likely to have an even more dominant effect for 100-year flood events due to the overflow of the flood protection infrastructure (most notably the flood retention basin) and the inundation of in particular industrial complexes. Accordingly, the climate change scenario would lead to approx. $€ 27.1$ million in flood damage. On the other hand, flood damage for 100 -year flood events is not expected to increase significantly due to land development because planning legislation in this Austrian Province restricts an increase in vulnerable land uses within $\mathrm{HQ}_{100}$ flooding zones (Office of the Styrian Government 2005). In 300-year flood events, climate change was also found to have a dominant impact on future flood damage potential, which would increase from currently around $€ 58.7$ million to $€ 75.9$ million $(+29 \%)$, versus $€ 61.9$ million or $+5 \%$ due to land 

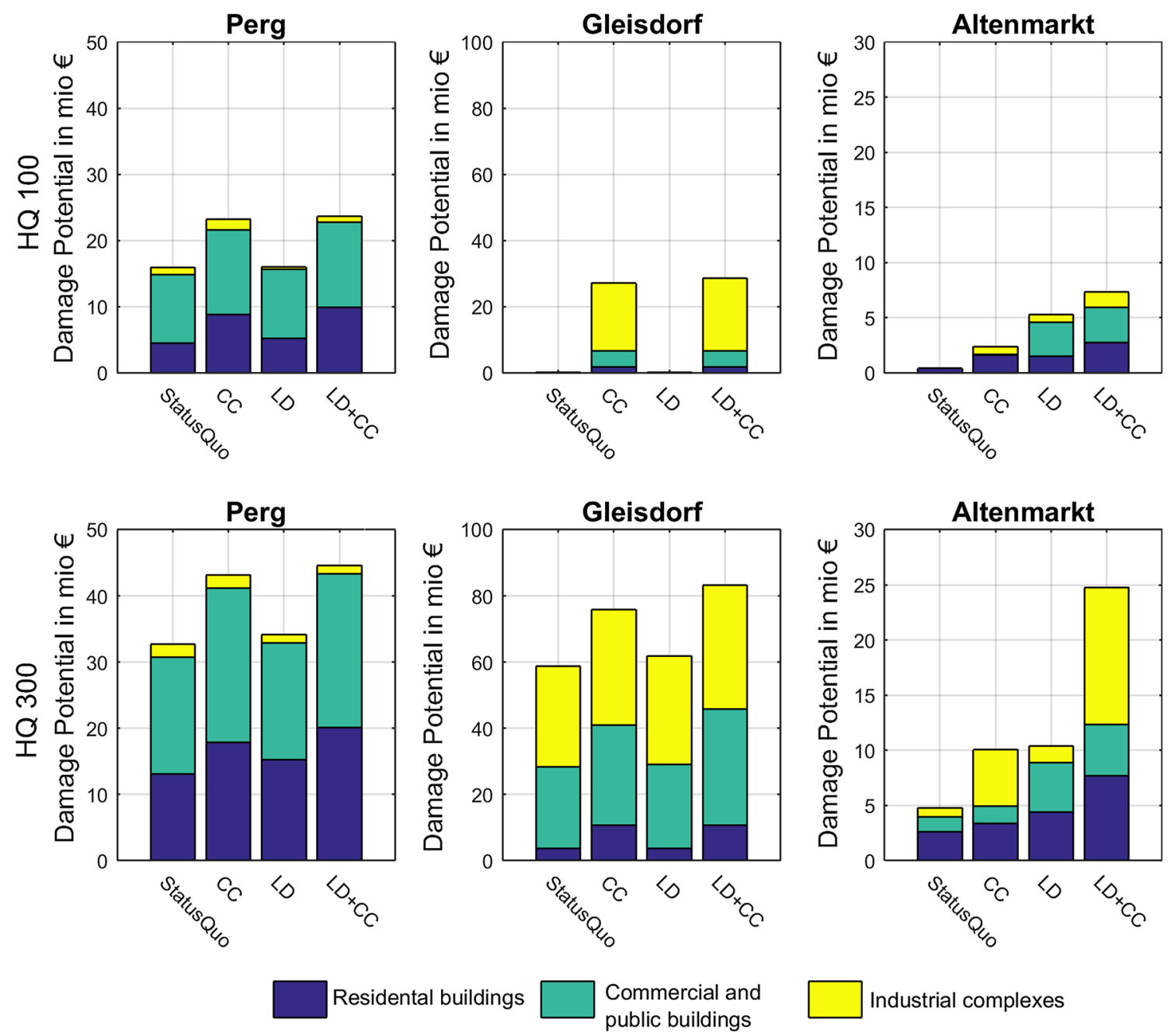

Fig. 5 Damage potential for different building categories for 100and 300-year flood events, evaluated for current design floods (Status $Q u o)$, for the climate change scenario with current land use $(C C)$, for

development and $€ 83.2$ million $(+42 \%)$ in the combined scenario.

In Altenmarkt, the total (current and future) flood damage potential is the lowest of all observed cases. Similar to Gleisdorf, the flood retention basins in the upper reaches of the Enns currently protect the main settlement to a large extent against major damages until a 100-year design flood. Climate change would lead to a partial overflow of flood protection infrastructure and would increase flood damages by about $€ 2$ million. Due to land development, on the other hand, the increase in flood damage potential would increase to approx. $€ 5.3$ million, meaning that in Altenmarkt land development is expected to be the stronger driver of future flood losses. Contrary to the situation in Gleisdorf, the provincial legislation of Salzburg is more lenient regarding land development in 100-year flood zones. For 300-year flood events, climate change and land development would lead to an equally high albeit different increase in flood the land development scenario with current flood hazard $(L D)$ and for the combined case of climate change and land development $(L D+C C)$

damage in Altenmarkt, with climate change affecting to a large extent industrial complexes and land development consisting predominantly of residential and commercial buildings. As substantial land development is to be expected in the extended $\left(\mathrm{HQ}_{300 \mathrm{cc}}\right)$ flooding areas, the combined effect of the climate change and land development scenarios $(\mathrm{CC}+\mathrm{LD})$ would lead to a particularly strong increase in flood damage potential.

To illustrate the sensitivity of future flood risk to the effects of climate change and/or land development, the respective scenarios can be expressed in the change of the annual expected damages (see Fig. 6). The changes refer to the current annual expected damages per capita for floods with low recurrence interval $\left(\geq \mathrm{HQ}_{100}\right)$, which were calculated to be $€ 45$ for Perg, $€ 50$ for Gleisdorf and $€ 5$ for Altenmarkt.

The figure shows that for Perg and Gleisdorf climate change is detected as the dominant risk driver, as land 

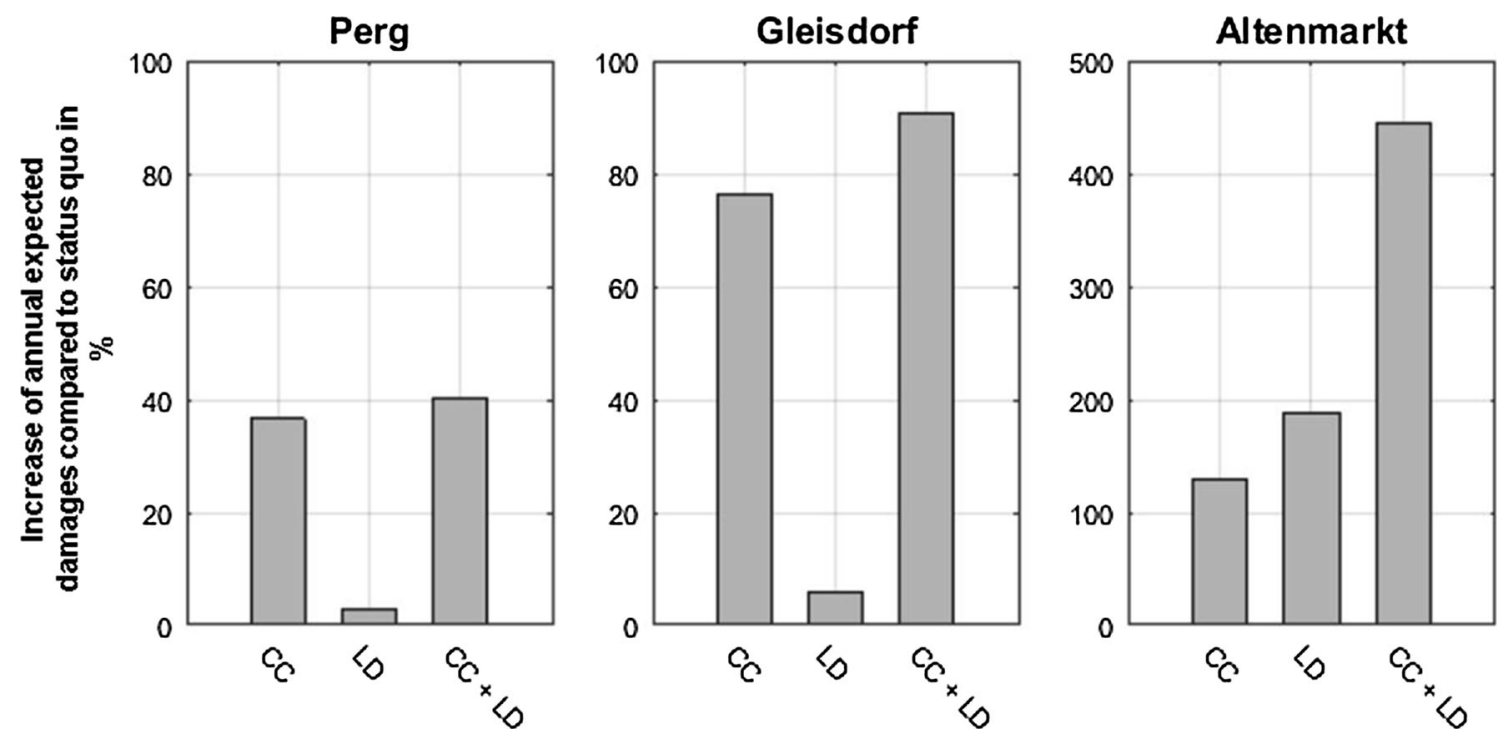

Fig. 6 Relative changes in mean annual expected flood damages for the scenarios climate change $(C C)$, land development $(L D)$ and combined case of climate change and land development $(L D+C C)$, based on the current annual expected damages per capita

development only leads to a slight increase in mean annual expected flood damages. In Altenmarkt, however, land development is expected to be the stronger driver of future flood risk.

\section{Discussion}

The above findings illustrate the possible impacts of climate change and land development on future flood risk in selected Austrian flood-prone municipalities. In contrast to studies analysing if or to which extent climate change influences the frequency of flood events in Austria (cf. Blöschl et al. 2011; Nachtnebel et al. 2014) and in Europe (cf. Kundzewicz 2012; Madsen et al. 2014), this contribution shows how a (literature-derived) $10 \%$ increase in flood peaks would affect the intensity of 100- and 300-year flood events. With regard to future changes in flood hazard exposure, this study did not resort to regionalized land-use models, as used in comparable studies (cf. Bouwer et al. 2010; Maaskant et al. 2009; de Moel et al. 2011), but applied a detailed plot-level assessment, thus addressing the need to "take into account the exact location of landuse change in flood-prone areas" (Bouwer et al. 2010).

By applying the same climate change allowance in all case studies we were able to identify two significant contextual conditions, which influence the sensitivity of future flood risk to climate change-related increases in peak discharge. For one, the topography and structure of the floodplain determine the extent of the increase in flooding intensities (i.e. inundation area and inundation depth), as, for example, wider and deeper river channels combined with steeper gradients can absorb higher peak discharges. This interrelationship corresponds to the findings documented for the whole of Austria (Nachtnebel and Apperl 2015). Secondly, the impact of future increases in flood hazard depends on the effectiveness of flood protection infrastructure to withstand the climate change allowance. In some cases, the increase in peak discharges could lead to the overflow (and possibly breaching) of retention basins or dikes, while in other cases the flood protection schemes persist due to a considered safety margin. In this context, the findings highlight the importance of considering possible climate-induced changes in flood peaks for residual risk analysis, as flood defence infrastructure fulfils its protective function up to a defined design magnitude and existing safety margins (e.g. freeboard) are not intended to compensate possible climate-induced changes in peak discharge.

The variation in the influence of land development on future flood risk between the three case studies also illustrates the need for contextualizing local land-use change. Whereas the supply of building land (i.e. the amount of undeveloped building land) in floodplains generally represents a key driver of flood risk, the intensity of flood damage increase is determined by the type of building land (e.g. residential, commercial, industrial) and the corresponding damage values. In this regard, the spatial distribution of building land within the floodplain is crucial, as the damage potential is directly related to the inundation depth (which usually decreases with distance from the river channel). Future flood hazard exposure, however, is not only "supply driven" but also "demand driven", as strong socio-economic growth increases the need to develop land 
in potential hazard areas, most notably in alpine areas (with a limited share of land suitable for permanent settlement) where locations outside potential floodplains are rare, especially for commercial and industrial land uses. Finally, future changes in flood risk also depend on the regional legal and institutional frameworks, because spatial planning laws and building codes (which regulate land development in flood hazard zones) are different in each Austrian Province.

As flood-related planning decisions generally come with long-term commitment and a strong demand for anticipating future developments (Hallegate 2009), the above insights are of immediate relevance for implementing an anticipatory management of flood risk (Nordbeck et al. 2015). In a series of scientist-stakeholder workshops that were conducted in all three case study areas, we showed that the micro-scale assessment of both hazard and exposure dynamics can help identify (thematic and spatial) priority areas of adapting to future changes in flood risk (Löschner et al. 2016). For instance, in those flood-prone municipalities where the climate change allowance is likely to increase flooding intensities (additional) flood protection measures or flood mitigation measures may be considered. An expected increase in flood damage potential due to settlement development in floodplains, on the other hand, allows planning authorities to apply local planning instruments to (re-)direct land development or to reduce damage potentials by promoting structural adaptation measures for buildings in potential flood hazard areas.

Acknowledgments The findings presented in this paper were developed in the project RiskAdapt (Anticipatory Flood Risk Management under Climate Change Scenarios: From Assessment to Adaptation; Grant Number: KR11AC0K00275). The project was funded within the Austrian Climate Research Program (ACRP) by the Austrian Climate and Energy Fund. For more information, see https:// riskadapt.boku.ac.at/. Open access funding provided by University of Natural Resources and Life Sciences Vienna (BOKU).

Open Access This article is distributed under the terms of the Creative Commons Attribution 4.0 International License (http://crea tivecommons.org/licenses/by/4.0/), which permits unrestricted use, distribution, and reproduction in any medium, provided you give appropriate credit to the original author(s) and the source, provide a link to the Creative Commons license, and indicate if changes were made.

\section{References}

APCC-Austrian Panel on Climate Change (2014) Austrian assessment report climate change 2014 (AAR14). Austrian Academy of Sciences Press, Vienna

Barredo JI (2007) Major flood disasters in Europe: 1950-2005. J Nat Hazards 42:125-148. doi:10.1007/s11069-006-9065-2

Barredo JI (2009) Normalised flood losses in Europe: 1970-2006. Nat Hazards Earth Syst Sci 9:97-104. doi:10.5194/nhess-9-97-2009
Blöschl G, Viglione A, Merz R, Parajka J, Salinas J, Schöner W (2011) Auswirkungen des Klimawandels auf Hochwasser und Niederwasser. Oesterr Wasser Abfallwirtsch 63:21-30

BMLFUW-Austrian Federal Ministry of Agriculture, Forestry, Environment and Water Management (2011a) Anpassungsstrategien an den Klimawandel für Österreichs Wasserwirtschaft. Vienna

BMLFUW-Austrian Federal Ministry of Agriculture, Forestry, Environment and Water Management (2011b) Vorläufige Bewertung des Hochwasserrisikos 2011. Bericht zur Umsetzung in Österreich, Vienna

Bouwer L, Bubeck P, Aerts J (2010) Changes in future flood risk due to climate and development in a Dutch polder area. Glob Environ Change 20:463-471. doi:10.1016/j.gloenvcha.2010.04. 002

BUWAL_Bundesamt für Umwelt, Wald und Landschaft (1999a) Risikoanalyse bei gravitativen Naturgefahren-Methode. Bern

BUWAL_Bundesamt für Umwelt, Wald und Landschaft (1999b) Risikoanalysen bei gravitativen Naturgefahren-Fallbeispiele und Daten. Bern

Christensen JH, Christensen OB (2002) Severe summertime flooding in Europe. Nature 421:805-806. doi:10.1038/421805a

de Moel H, Aerts J, Koomen E (2011) Development of flood exposure in the Netherlands during the 20th and 21st century. Glob Environ Change 21:620-627. doi:10.1016/j.gloenvcha.2010.12. 005

Elmer F, Hoymann J, Düthmann D, Vorogushyn S, Kreibich H (2012) Drivers of flood risk change in residential areas. Nat Hazards Earth Syst Sci 12:1641-1657. doi:10.5194/nhess-12-1641-2012

European Union (2007) Directive 2007/60/EC of the European parliament and of the council of 23 October 2007 on the assessment and management of flood risks

Evans E, Ashley R, Hall J, Penning-Rowsell E, Saul A, Sayers P, Watkinson A (2004) Foresight future flooding, scientific summary: vol 2: managing future risks. Office of Science and Technology, London

Formayer H, Kromp-Kolb H (2009) Hochwasser und Klimawandel. Auswirkungen des Klimawandels auf Hochwasserereignisse in Österreich (Endbericht WWF 2006). BOKU-Met Report 7. http://www.boku.ac.at/met/report/BOKU-Met_Report_07_ online.pdf. Accessed 27 Oct 2015

Gobiet A, Kotlarski S, Beniston M, Heinrich G, Rajczak J, Stoffel M (2014) 21st century climate change in the European Alps-a review. Sci Total Environ 493:1138-1151. doi:10.1016/j.scito tenv.2013.07.050

Gouldby B, Samuels P (2005) Language of risk-project definitions. FLOODsite Repor T32-04-01. http://www.floodsite.net/html/ partner_area/project_docs/floodsite_language_of_risk_v4_0_p1. pdf. Accessed 15 May 2016

Hallegate S (2009) Strategies to adapt to an uncertain climate change. Glob Environ Change 19:240-247. doi:10.1016/j.gloenvcha. 2008.12.003

Hartmann DL, Klein Tank AMG, Rusticucci M, Alexander LV, Brönnimann S, Charabi Y, Dentener FJ, Dlugokencky EJ, Easterling DR, Kaplan A, Soden BJ, Thorne PW, Wild M, Zhai PM (2013) Observations: atmosphere and surface. In: Stocker TF, Qin D, Plattner GK, Tignor M, Allen SK, Boschung J, Nauels A, Xia Y, Bex V, Midgley PM (eds) Climate change. The physical science basis. Contribution of working group I to the fifth assessment report of the intergovernmental panel on climate change. Cambridge University Press, Cambridge, pp 159-254. doi:10.1017/CBO9781107415324.008

Hennegriff W, Kolokotronis V, Weber H, Bartels H (2006) Climate change and floods-findings and adaptation strategies for flood protection (in German). KA-Abwasser. Abfall 53(8):770-779 
HISTALP-Historical Instrumental Climatological Surface Time Series of the Greater Alpine Region (2013) HISTALP annual report for Austria 2013. http://www.zamg.ac.at/cms/de/klima/ news/histalp/histalp-langzeitklimareihen-oesterreichjahresber icht-2013. Accessed 23 Sept 2015

Hydrotec (2014) Das 2D Strömungsmodell Hydro_AS-2D. Hydrotec Ingenieurgesellschaft http://www2.hydrotec.de/unternehmen/ hydrothemen/hydrothemen07/hydro-as-2d/. Accessed $12 \mathrm{Sept}$ 2015

Kreft M (2011) Quantifying the impacts of climate related natural disasters in Australia and New Zealand. Munich Re, Wellington

Kundzewicz ZW (ed) (2012) Changes in flood risk in Europe. IAHS Special Publication 10. CRC Press, Balkema

Kundzewicz ZW, Lugeri N, Dankers R, Hirabayashi Y, Döll P, Pińskwar I, Dysarz T, Hochrainer S, Matczak P (2010) Assessing river flood risk and adaptation in Europe-review of projections for the future. Mitig Adapt Strateg Glob Change. doi:10.1007/ s11027-010-9213-6

LfU-Landesamt für Umwelt (2005) SonderthemaKlimaänderungsfaktoren bei Planungen für den Hochwasserschutz. Gewässerkundlicher Jahresbericht für Bayern

Löschner L, Nordbeck R, Scherhaufer P, Seher W (2016) Scientistsstakeholder workshops: an integrated assessment of flood risk and an evaluation of local response options. Environ Sci Policy 55:345-552. doi:10.1016/j.envsci.2015.08.003

Maaskant B, Jonkman S, Bouwer L (2009) Future risk of flooding: an analysis of changes in potential loss of life in South Holland (The Netherlands). Environ Sci Policy 12:157-169. doi:10.1016/ j.envsci.2008.11.004

Madsen H, Lawrence D, Lang M, Marinkova M, Kjeldsen TR (2014) Review of trend analysis and climate change projections of extreme precipitation and floods in Europe. $\mathrm{J}$ Hydrol 519:3634-3650. doi:10.1016/j.jhydrol.2014.11.003

Merz B, Kreibich H, Thieken A, Schmidke R (2004) Estimation uncertainty of direct monetary flood damage to buildings. Nat Hazards Earth Syst Sci 4:153-163. doi:10.5194/nhess-4-1532004

Merz B, Hall J, Disse M, Schumann A (2010) Fluvial flood risk management in a changing world. Nat Hazards Earth Syst Sci 10:509-527. doi:10.5194/nhess-10-509-2010

Messner F, Meyer V (2006) Flood damage, vulnerability and risk perception-challenges for flood damage research. In: Schanze J, Zeman E, Marsalek J (eds) Flood risk management. Hazards vulnerability and mitigation measures. Springer eBook, Nato Science Series, vol 67, pp 149-167

Munich Re (2013) Natural catastrophes 2012. Analyses, assessments, positions. In: Topic geo, 2013 issue. Munich RE, Munich

Nachtnebel H, Apperl B (2014) Wasserwirtschaftliche Entwicklung in Überflutungsgebieten-Instrumentenevaluierungsstudie. Amt der oberösterreichischen Landesregierung/University of Natural Resources and Life Sciences (BOKU), Vienna

Nachtnebel HP, Apperl B (2015) Beurteilung des HochwasserSchadenspotenzials unter dynamischen Bedingungen. Österr Wasser- und Abfallw 67:120-130. doi:10.1007/s00506-0150220-4

Nachtnebel HP, Apperl B, Zach R, Wagendorfer S (2013) Pilotprojekt: Hochwasserrisikomanagementplan Gleisdorf. Amt der steiermärkischen Landesregierung, Graz

Nachtnebel HP, Dokulil M, Kuhn M, Loiskandl W, Sailer R, Schöner, W (2014) Influence of climate change on the hydrosphere. In: Austrian Panel on Climate Change (APCC) Austrian Assessment Report Climate Change 2014 (AAR14). Austrian Academy of Sciences Press, Vienna, pp 411-466

Nordbeck R, Apperl B, Herrnegger M, Hogl K, Löschner L, Nachtnebel HP, Scherhaufer P, Schulz K, Seher W, Senoner T (2015) Anticipatory flood risk management under climate change scenarios: from assessment to adaptation (RiskAdapt), final report. University of Natural Resources and Life Sciences (BOKU), Vienna

OeWAV-Österreichischer Wasser- und Abfallwirtschaftsverband (2010) Auswirkungen des Klimawandels auf Hydrologie und Wasserwirtschaft in Österreich. Österreichischer Wasser- und Abfallwirtschaftsverband (ÖWAV), Vienna

OeWAV-Österreichischer Wasser- und Abfallwirtschaftsverband (2014) ÖWAV-Positionspapier-Strategie 2013+-Schutz vor Hochwasser und Muren. Österreichischer Wasser- und Abfallwirtschaftsverband (ÖWAV), Vienna

Office of the Styrian Government (2005) Programme for flood-safe development in settlement area, LGBL.Nr. 117/2005

Sayers PB, Hall JW, Meadowcroft IC (2002) Towards risk-based flood hazard management in the UK. Proc ICE, Civil Eng 150:36-42

Schanze J, Hutter G, Offert A, Penning-Rowsell EC, Parker D, Harries T, Koniger P, Kuhlicke C, Meyer V, Nachtnebel HP, Holzmann H, Neuhold C, Olfert A, Schildt A (2008) Systematisation, evaluation and context conditions of structural and non-structural measures for flood risk reduction. In: CRUE research report no. I-1, London

Smith K (1996) Environmental hazards: assessing risk and reducing disaster. Routledge, London

Smith K, Ward R (1998) Floods: physical processes and human impacts. Wiley, Chichester

UNISDR - United Nations International Strategy for Disaster Reduction (2009) Terminology on disaster risk reduction. United Nations, Geneva

UNISDR - United Nations International Strategy for Disaster Reduction (2011) Global assessment report on disaster risk reductionrevealing risk, redefining development. United Nations, Geneva 